\title{
Differential expression of laminin receptors in human hepatocellular carcinoma
}

\author{
I Ozaki, K Yamamoto, T Mizuta, S Kajihara, N Fukushima, Y Setoguchi, F Morito, \\ T Sakai
}

\begin{abstract}
Background-Laminin receptors are involved in cell-extracellular matrix interactions in malignant cells that show invasion and metastasis. Hepatocellular carcinoma frequently shows early invasion into blood vessels, and intrahepatic and extrahepatic metastases. However, the role of laminin receptors in hepatocellular carcinoma is unknown.

Aims-To examine the expression of mRNA for laminin receptors and their isoforms in hepatocellular carcinoma.

Methods-The expression of several laminin receptors, including $\alpha 1$ integrin, $\alpha 6$ integrin and its isoforms $\alpha 6 \mathrm{~A}$ and $\alpha 6 \mathrm{~B}, \beta 1$ integrin and its isoforms $\beta 1 A$ and $\beta 1 B$, and $32 \mathrm{kD} / 67 \mathrm{kDa}$ laminin binding protein was examined in human hepatocellular carcinomas and non-cancerous liver tissues using the reverse transcription polymerase chain reaction.

Results- $\alpha 6$ Integrin, $\beta 1$ integrin, and laminin binding protein showed notably increased expression in hepatocellular carcinoma, compared with noncancerous liver tissue, although the $\alpha 1$ integrin did not show a significant change. Furthermore, $\beta 1 B$ integrin, a splicing variant of $\beta 1$ integrin, was overexpressed in hepatocellular carcinoma while the $\beta 1 \mathrm{~A}$ integrin isoform did not show significant changes between hepatocellular carcinoma and surrounding non-cancerous liver tissue.

Conclusions-The differential upregulation of laminin receptors and their splicing isoforms was shown in hepatocellular carcinoma, suggesting that certain laminin receptors and their isoforms may be involved in the development and progression of hepatocellular carcinoma.

(Gut 1998;43:837-842)
\end{abstract}

Keywords: laminin receptor; integrin $\alpha 6 \beta 1$; hepatocellular carcinoma

The process of tumour development and metastasis appears to involve alterations in cell-cell and/or cell-extracellular matrix (ECM) interactions mediated by specific receptors. The interaction between transformed cells and the basement membrane is an important step in the development of invasion and metastasis. ${ }^{1}$ Laminin, one of the major components of the basement membrane, was first purified from tumour cells as a heterotrimeric protein consisting of $\mathrm{A}, \mathrm{B} 1$, and $\mathrm{B} 2$ subunits, $^{2}$ later renamed $\alpha 1, \beta 1$, and $\gamma 1{ }^{3}$ Recently homologues of laminin subunits have been cloned and revealed a variety of heterogeneity of laminins. To date, at least 11 distinct laminin isoforms have been identified. ${ }^{34}$ It has been reported that certain fragments of laminin inhibit the metastatic activity of some malignant cells, ${ }^{5}{ }^{6}$ and the other fragments enhance the metastatic activity of tumour cells. ${ }^{7}$ These effects are thought to be mediated by specific laminin receptor(s). Therefore it may be useful to examine the expression of laminin receptors on malignant cells, to understand better their role in carcinogenesis, invasion, and metastasis.

Hepatocellular carcinoma (HCC) frequently shows invasion into blood vessels at an early stage as well as intrahepatic and extrahepatic metastases. ${ }^{8}$ The interaction between liver cancer cells and laminin through specific laminin receptors may be involved in the process of hepatocarcinogenesis. A variety of laminin receptors have been identified, including integrin which is a heterodimer composed of one $\alpha$ and one $\beta$ subunit, and non-integrin families (reviewed in $\mathrm{Mecham}^{9}$ ). However, little data is available on the alterations of the ECM receptors in HCC, and their role in vascular invasion and metastasis. We examined the expression of several laminin receptor mRNAs, including $\alpha 1$ integrin, $\alpha 6$ integrin and its isoforms $\alpha 6 \mathrm{~A}$ and $\alpha 6 \mathrm{~B}, \beta 1$ integrin and its isoforms $\beta 1 \mathrm{~A}$ and $\beta 1 \mathrm{~B}$, and $32 / 67 \mathrm{kDa}$ laminin binding protein (LBP), in human HCC tissue using a semiquantitative reverse transcription polymerase chain reaction (RT-PCR) method. Here we show the usefulness of semiquantitative RT-PCR, and document the differential upregulation of laminin receptors and their splicing variants in human HCC.

\section{Materials and methods}

HUMAN LIVER SAMPLES

We examined tumour and corresponding noncancerous liver tissue in 16 patients with HCC. There were two women and 14 men (mean (SD) age 60.7 (5.0) years, range 55-67). All 16 patients were positive for antihepatitis $C$ virus antibody; four had chronic hepatitis and 12 liver cirrhosis diagnosed by histopathological examination under a light microscope. We also examined liver tissue from three subjects with normal liver histology.

The liver specimens were obtained by surgical resection performed for treatment of the hepatic neoplasms (eight patients), or by autopsy performed within three hours of death (eight patients) at the hospital of the Saga Medical School. A portion of each human liver
Accepted for publication 16 June 1998 
Table 1 Oligonucleotide primers used for RT-PCR analysis

\begin{tabular}{|c|c|c|c|c|c|}
\hline & Sequence of primers & $\begin{array}{l}\text { Size of RT-PCR } \\
\text { products }(b p)\end{array}$ & References & $\begin{array}{l}\text { Enzymes used for } \\
\text { confirmation }\end{array}$ & $\begin{array}{l}\text { Expected size of } \\
\text { cleavage products } \\
\text { (bp) }\end{array}$ \\
\hline LBP & $\begin{array}{l}\text { 5'-TGCAACAACAAGGGAGCTCAC-3' } \\
\text { 5'-TCCATCAACCATTTTTCCAT-3' }\end{array}$ & $450 \mathrm{bp}$ & 16 & PstI & $348+102$ \\
\hline \multicolumn{6}{|c|}{ - the- } \\
\hline$\alpha 1$ & $\begin{array}{l}\text { 5'-GCCCCAGTAGAGGACATGTTT-3' } \\
\text { 5'-ACATATTCCAGTTGTATAATG-3' }\end{array}$ & $324 \mathrm{bp}$ & 13 & HinfI & $182+142$ \\
\hline$\alpha 6$ & $\begin{array}{l}\text { 5'-TCCCTGAACCTAACGGAGTCT-3' } \\
\text { 5'-ATGTCCAAGTAGTTCAGTTTG-3' }\end{array}$ & $254 \mathrm{bp}$ & 14 & XhoI & $196+58$ \\
\hline$\alpha 6 \mathrm{~A} / \mathrm{B}$ & $\begin{array}{l}\text { 5'-GAACTGTGTGAACATCAGA-3' } \\
\text { 5'-ATCCTTACAGCATGGTATCG-3' }\end{array}$ & $\begin{array}{l}\alpha 6 \mathrm{~A} 500 \mathrm{bp} \\
\alpha 6 \mathrm{~B} 370 \mathrm{bp}\end{array}$ & 14,18 & & \\
\hline$\beta 1$ & $\begin{array}{l}\text { 5'-ACAGCAGAGAAGCTGAAGCCA-3 } \\
\text { 5'-GAGCTTAGCTGGTGTTGTGC-3' }\end{array}$ & $306 \mathrm{bp}$ & 15 & BglII & $198+108$ \\
\hline$\beta 1 \mathrm{~A}$ & $\begin{array}{l}\text { 5'-AGAATCCAGAGTGTCCCACTGG-3' } \\
\text { 5'-TTCCCTCATACTTCGGATTGA-3' }\end{array}$ & $238 \mathrm{bp}$ & 15,19 & & \\
\hline$\beta 1 \mathrm{~B}$ & $\begin{array}{l}\text { 5'-ACTTATGTATTAGCTGTCAG-3' } \\
\text { 5'-CATTGAATAGCTTGCTACCA-3' }\end{array}$ & $272 \mathrm{bp}$ & 15,19 & & \\
\hline$\beta$-actin & $\begin{array}{l}\text { 5'-GTGGGGCGCCCCAGGCACCA-3' } \\
\text { 5'-CTCCTTAATTGTCACGCACGATTC-3' }\end{array}$ & $540 \mathrm{bp}$ & 17 & TaqI & $430+110$ \\
\hline
\end{tabular}

RT-PCR, reverse transcription polymerase chain reaction; LBP, laminin binding protein.

specimen was used for histological diagnosis by light microscopy. The remaining liver tissue was immediately frozen in liquid nitrogen and stored at $-80^{\circ} \mathrm{C}$ for RNA extraction. The histological grading of HCC was based on Edmondson's grading system, ${ }^{10}$ and comprised two grade I, 11 grade II, and three grade III disease. The clinical stage was based on the TNM classification system of the UICC, ${ }^{11}$ and comprised two stage I, three stage II, one stage III, and nine stage IV disease.

RNA EXTRACTION AND CONFIRMATION OF INTEGRITY

Total RNA was extracted from liver tissue by using the guanidinium method as previously described. ${ }^{12}$ After RNA extraction, to confirm the integrity of total RNA extracted, especially from postmortem liver samples, $1 \mu \mathrm{g}$ of each total RNA sample was electrophoresed in an agarose gel, stained with ethidium bromide, visualised under ultraviolet (UV) light, and compared with the total RNA extracted from surgical liver samples. Postmortem livers of 23 patients were subjected to total RNA extraction; only the RNA of eight patients, which did not show significant degradation of $28 \mathrm{~S}$ and $18 \mathrm{~S}$ ribosomal RNA, was used for the experiment. mRNA expression of several genes was compared between surgical liver samples and postmortem liver samples. Semiquantitative RT-PCR of oncogene Ets-1, one of the extracellular matrix components of the laminin $\alpha 2$ chain, and housekeeping gene GAPDH

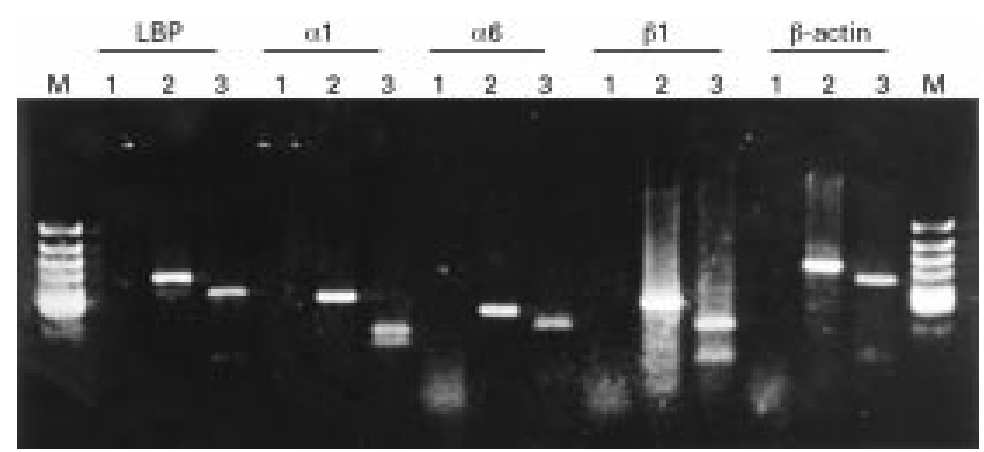

Figure 1 RT-PCR products of laminin binding protein (LBP), a1 integrin, a6 integrin, $\beta 1$ integrin, and $\beta$-actin separated by $2 \%$ agarose gel electrophoresis. Lane 1: RT-PCR without reverse transcriptase. Lane 2: RT-PCR with reverse transcriptase. Lane 3: the products of lane 2 digested with a specific restriction enzyme based on the sequence data. were performed, and results showed no significant differences in the expression of these genes between surgical samples and postmortem samples (data not shown).

\section{OLIGONUCLEOTIDES}

Table 1 lists the sequences of the oligonucleotide primers used for the RT-PCR reactions.

\section{RT-PCR AND CONFIRMATION OF RT-PCR}

PRODUCTS

cDNA (complementary DNA) was synthesised from $1 \mu \mathrm{g}$ of total RNA with or without reverse transcriptase with random primers (Takara, Kyoto). The reaction mixture was then subjected to PCR amplification with specific forward and reverse oligonucleotide primers for 40 cycles consisting of heat denaturation $\left(94^{\circ} \mathrm{C}\right.$ for 1.5 minutes), annealing $\left(50^{\circ} \mathrm{C}\right.$ for 1.5 minutes), and extension $\left(72^{\circ} \mathrm{C}\right.$ for two minutes). PCR products were size fractionated on $2 \%$ agarose gels, and visualised under UV light. Aliquots of each RT-PCR product were used for digestion with specific restriction enzymes to confirm the sequences of the products: $\alpha 1$ with HinfI, $\alpha 6$ with XhoI, $\beta 1$ with BglII, LBP with PstI, and $\beta$-actin with TaqI. All of the restriction enzymes used were purchased from Takara.

\section{SEMIQUANTITATIVE RT-PCR}

cDNA was synthesised from $1 \times 10^{-5}$ to $1 \mu \mathrm{g}$ of total RNA with reverse transcriptase (BRL, Gaithersburg, Maryland, USA) using random primers (Takara). Subsequently, the reverse transcriptase reaction mixture was used for PCR amplification with forward and reverse oligonucleotide primers, using a PCR kit with Taq DNA polymerase (Perkin Elmer/Cetus, Norwalk, Connecticut, USA). Each PCR reaction mixture was subjected to $15-40$ cycles consisting of heat denaturation $\left(94^{\circ} \mathrm{C}\right.$ for 1.5 minutes), annealing $\left(50^{\circ} \mathrm{C}\right.$ for 1.5 minutes), and extension $\left(72^{\circ} \mathrm{C}\right.$ for two minutes). The PCR products were size fractionated on $2 \%$ agarose gels, and visualised under UV light. The PCR products were quantified using a negative film of PCR products with densitometric scanning. Isoform specific primers reported previously were used for the detection 

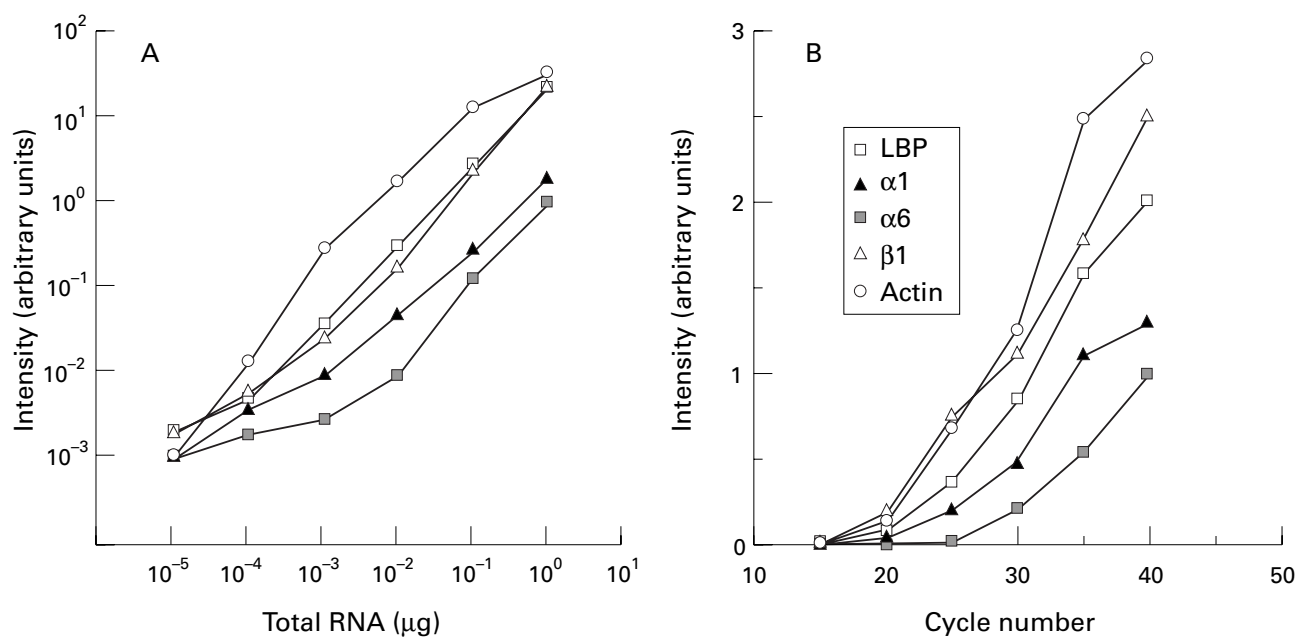

Figure 2 Densitometric semiquantification of the RT-PCR products showed association with the amount of RNA applied $(A)$, and the number of PCR cycles (B).

of the $\alpha 6$ and $\beta 1$ isoforms (table 1 ). Reverse transcription was performed from $1 \mu \mathrm{g}$ of total RNA, and 30 cycles of PCR were performed.

STATISTICAL ANALYSIS

The Dunnet test was used for non-parametric multiple comparisons of RT-PCR products
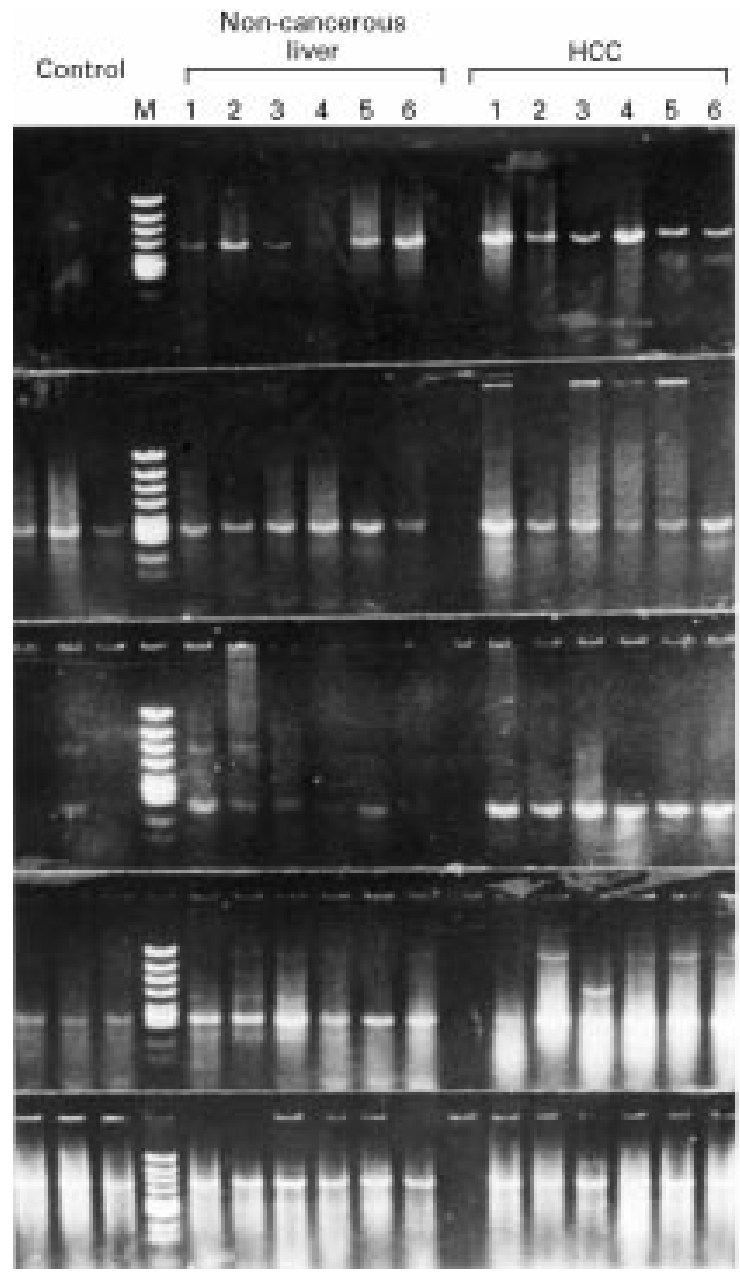

a1-Integrin

«6-Intergrin

Figure 3 Gene expression of LBP, a1 integrin, a 6 integrin, $\beta 1$ integrin, and $\beta$-actin in six representative samples of human liver tissue detected by RT-PCR. Identical lane numbers indicate that the tissue was obtained from the same patient with chronic liver disease and HCC.
LBP $450 \mathrm{bp}$ $324 \mathrm{bp}$ $254 \mathrm{bp}$

among the normal controls, chronically diseased livers, and hepatocellular carcinomas.

\section{Results}

DETECTION AND CONFIRMATION OF THE RT-PCR PRODUCTS

To confirm that the RT-PCR products were RNA dependent, PCR was performed with or without reverse transcription (fig 1, lanes 1 and 2 of each RT-PCR). All the samples without reverse transcription showed no PCR products, indicating that these products were RNA dependent. To identify the sequences of the RT-PCR products, these products were digested with specific restriction enzymes, based on their sequences (table 1). Each reaction with specific restriction enzymes showed fragments of the predicted size (fig 1, lane 3 of each RT-PCR).

SEMIQUANTIFICATION OF RT-PCR

We first determined that the intensity of the signals obtained by this RT-PCR method was dependent on both the amount of RNA present, and on the number of cycles of PCR. ${ }^{20}$ We performed reverse transcription from serially diluted RNA samples, 1 to $1 \times 10^{-5} \mu \mathrm{g}$, and subsequently subjected these samples to PCR for 30 cycles. Following agarose gel electrophoresis and staining with ethidium bromide, the intensities of the visualised PCR products were evaluated by densitometric scanning (fig 2A). Results showed that the signal increased exponentially according to the amount of total RNA, except for $\beta$-actin, which $\begin{array}{cl}31-\text { Intergrin } & \text { reached a plateau at } 1 \times 10^{-1} \mu \mathrm{g} \text { of total RNA. } \\ 306 \mathrm{bp} & \text { Next we performed RT-PCR from } 1 \mu \mathrm{g} \text { of total }\end{array}$ RNA while changing the number of PCR cycles from 15 to 40, to see changes in the signals according to the cycle number. The PCR products were visualised by ethidium bromide staining and UV light, and evaluated by densitometry (fig 2B). The signals of the RT-PCR products increased exponentially as the number of PCR cycles increased, although the signals showed a tendency to reach a plateau at more than 35 cycles. After working out these conditions, we examined the mRNA levels of 


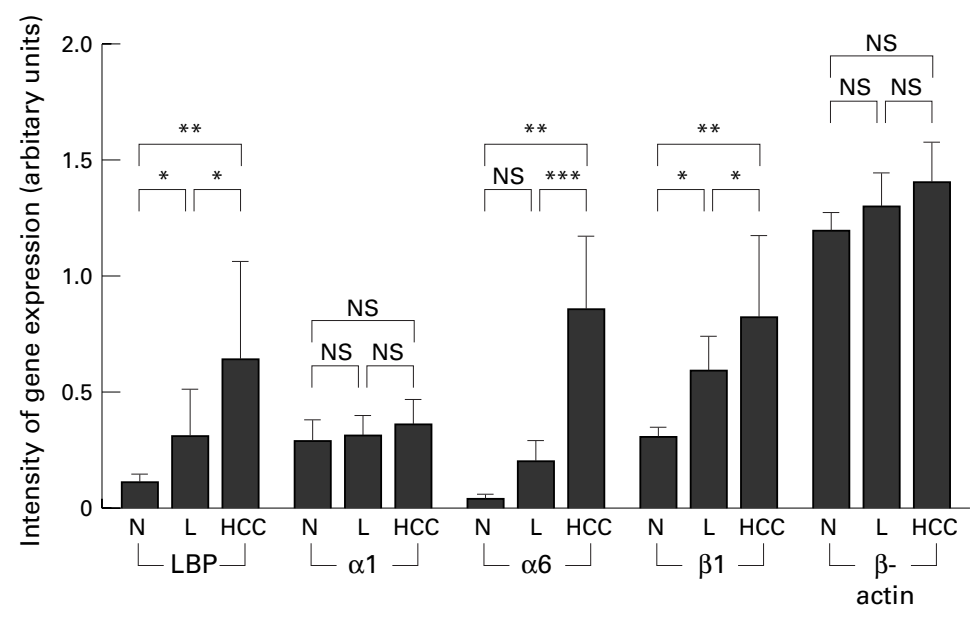

Figure 4 Semiquantitative analysis of LBP, a1 integrin, a6 integrin, $\beta 1$ integrin, and $\beta$-actin gene expression in normal liver $(N, n=3)$, chronically diseased, non-cancerous liver $(L, n=16)$, and HCC tissue $(n=16)$ detected by RT-PCR. Data are presented as mean (SD). ${ }^{\star} p<0.05 ;{ }^{\star *} p<0.01 ;{ }^{\star \star \star} p<0.001$.

the laminin receptors in human liver tissue using $1 \mu \mathrm{g}$ of total RNA and 30 cycles of PCR. The expression of $\beta$-actin mRNA was used as a loading control, using $1 \times 10^{-1} \mu \mathrm{g}$ of total RNA and 30 cycles of PCR.

EXPRESSION OF LAMININ RECEPTORS IN HUMAN HEPATOCELLULAR CARCINOMA

In normal liver tissue, $\alpha 1$ integrin and $\beta 1$ integrin mRNA were expressed highly, and $\alpha 6$ integrin and laminin binding protein (LBP) mRNA were also expressed, but weakly (figs 3 and 4$)$. In the non-cancerous liver tissue with chronic liver disease, $\beta 1$ integrin and LBP showed increased expression compared with normal liver tissue, although $\alpha 1$ integrin and $\alpha 6$ integrin did not show a significant increase (figs 3 and 4). Furthermore, $\alpha 6$ integrin, $\beta 1$ integrin, and LBP mRNAs are upregulated in HCC tissue compared with non-cancerous, chronically diseased liver tissue, although $\alpha 1$ integrin mRNA in HCC did not show a significant increase compared with noncancerous liver tissue (figs 3 and 4). There are some extra bands larger than expected in the $\beta 1$ integrin reaction in HCC samples in fig 3. Some were not reproducible, and some were sequenced directly, but no homology with the $\beta 1$ integrin sequence was found (data not

A
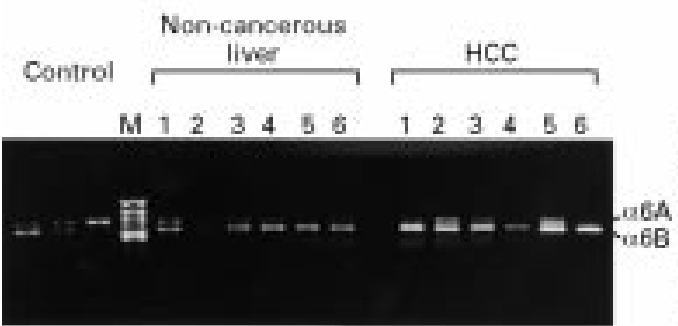

shown). Therefore, these products were considered to be non-specific mispriming products or as yet unknown gene products. When we compared the expression of two laminin receptors, $\alpha 6$ integrin and LBP, both of which showed increased expression in HCC tissue, $\alpha 6$ integrin showed a more prominent increase than did LBP. These data showed increased expression of some integrins and LBP in chronic viral liver disease, and showed further differential upregulation of $\alpha 6$ integrin, $\beta 1$ integrin, and LBP in human HCC.

EXPRESSION OF ISOFORMS OF $\alpha 6$ AND $\beta 1$ INTEGRIN The alternative splicing derived isoforms of $\alpha 6$ integrin, $\alpha 6 \mathrm{~A}$ and $\alpha 6 \mathrm{~B}$, and of $\beta 1$ integrin, $\beta 1 \mathrm{~A}$ and $\beta 1 \mathrm{~B}$, were amplified by RT-PCR with isoform specific primers. ${ }^{18} 19$ The same RT-PCR conditions used for the other integrins were used for the semiquantitative analysis of these isoforms. Although $\alpha 6 \mathrm{~A}$ and $\alpha 6 \mathrm{~B}$ mRNA were amplified by similar amounts in normal liver, much more $\alpha 6 \mathrm{~B}$ mRNA than $\alpha 6 \mathrm{~A}$ was amplified in chronically diseased, noncancerous liver tissue and HCC tissue (fig 5A). The intensity of total $\alpha 6$ integrin expression was increased in HCC compared with normal liver or non-cancerous, chronically diseased liver (fig 3). When the ratio of $\alpha 6 \mathrm{~B}: \alpha 6 \mathrm{~A}$ was compared among these groups, the amount of $\alpha 6 \mathrm{~B}$ mRNA expression in non-cancerous liver and HCC was significantly increased compared with normal liver (fig 5B). There was no difference in the $\alpha 6 \mathrm{~B}: \alpha 6 \mathrm{~A}$ ratio between chronically diseased, non-cancerous liver and HCC.

In the case of the $\beta 1$ integrin isoforms, $\beta 1 \mathrm{~A}$ and $\beta 1 \mathrm{~B}$, there was a significant difference in the expression pattern of these two isoforms (fig 6). The expression of $\beta 1 \mathrm{~B}$ was significantly increased in HCC compared with noncancerous liver tissue. Although the expression of $\beta 1 \mathrm{~A}$ integrin in chronic liver disease and HCC was increased compared with normal liver, there was no significant difference between HCC and non-cancerous liver tissue.

\section{Discussion}

Several laminin receptors including integrin have been reported to be present in normal and

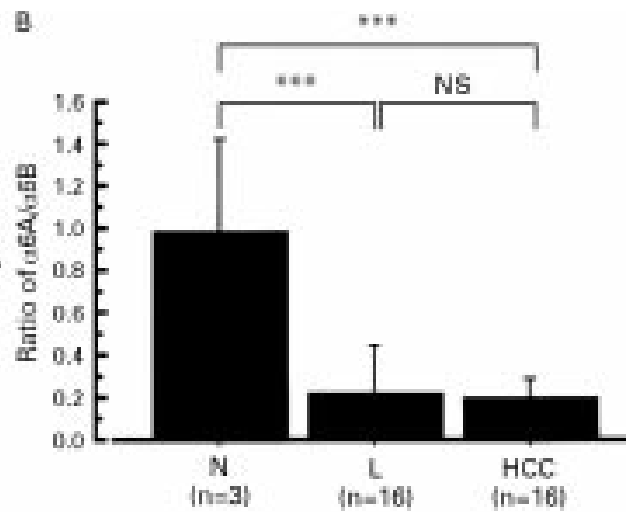

Figure 5 (A) Representative expression of the a 6 integrin isoforms, $a 6 A$ and $a 6 B$, by RT-PCR from six patients. (B) The a6B: 66 A ratio detected by densitometry in normal liver $(N, n=3)$, chronically diseased, non-cancerous liver $(L, n=16)$, and HCC $(n=16)$. Values are presented as mean $(S D) . \star \star \star x<0.001$. 
A

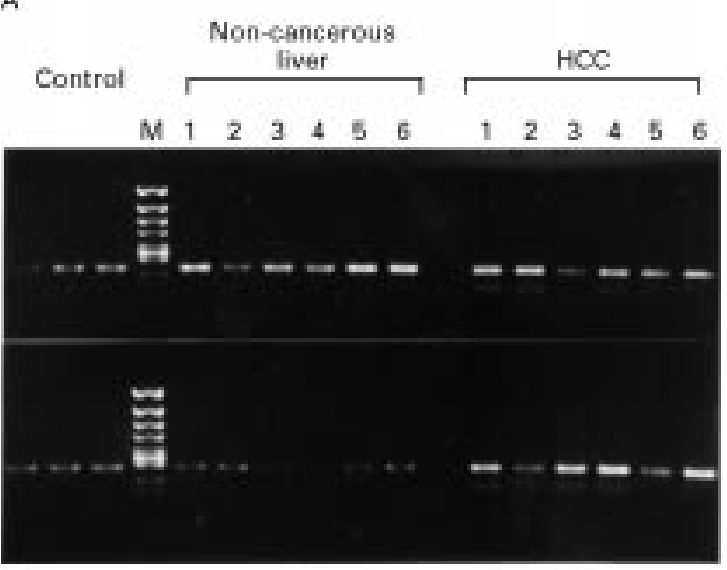

B1A-Integrin

B1e-Integrin

Q

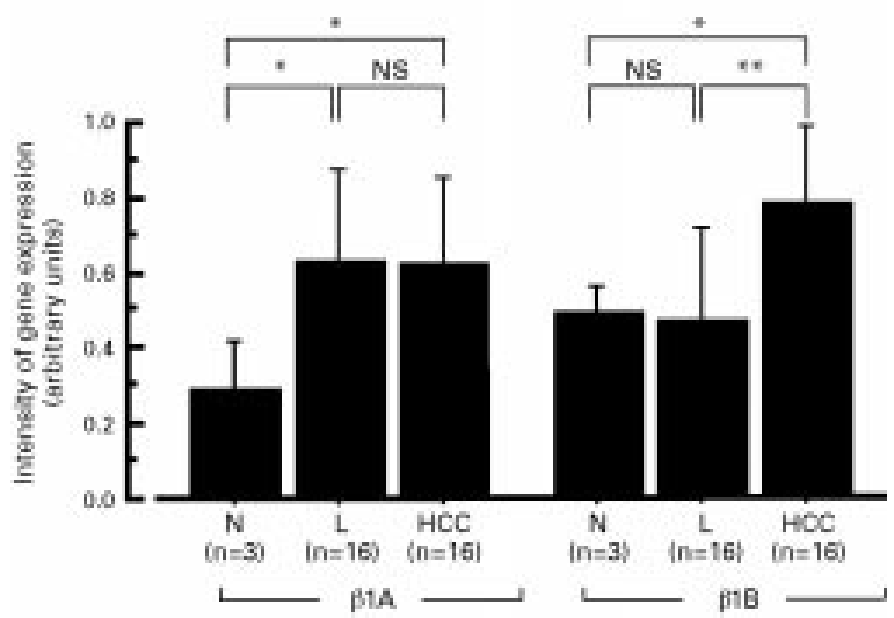

Figure 6 (A) Representative expression of the $\beta 1$ integrin isoforms, $\beta 1 A$ and $\beta 1 B$, by RT-PCR from six patients. (B) Semiquantification of $\beta 1 A$ and $\beta 1 B$ integrin in normal liver $(N, n=3)$, chronically diseased non-cancerous liver (L, $n=16)$, and HCC $(n=16)$. Data are presented as mean (SD). ${ }^{\star} p<0.05 ;{ }^{\star} p<0.01$.

fibrotic liver. ${ }^{21} 22$ In normal liver, integrin $\alpha 1$ and $\beta 1$ are expressed in hepatocyte and sinusoidal endothelial cells, although integrin $\alpha 6$ is only expressed in biliary cells and vascular endothelial cells. In inflammatory and fibrotic liver disease, $\alpha 6$ integrin showed increased expression in hepatocytes and sinusoidal endothelial cells. However, little is known about the expression of laminin receptors in liver tumours. Laminin receptor(s) are thought to be involved in a wide variety of biological events including development of tumour invasion and metastasis through cellcell and/or cell-ECM interactions. ${ }^{15-79}$ Usually, the vascular structure in hepatocellular carcinoma contains basement membrane components, such as type IV collagen and

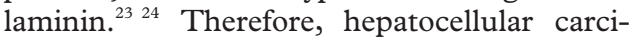
noma cells may have some interaction with laminin, the major component of the basement membrane, through their specific laminin receptor(s). It has been reported that one of the laminin receptors, LBP, shows increased expression in HCC, and that this correlates with the histological grade. ${ }^{24}$ Recently, an immunohistochemical study showed de novo expres- sion of several integrin molecules including $\alpha 2$, $\alpha 3$, and $\alpha 6$ integrin in HCC. ${ }^{25}$ More recently, overexpression of $\alpha 6$ integrin in human HCC has been reported. ${ }^{26}$ In the present study we investigated the mRNA levels of several laminin receptors in human HCC: LBP and two integrins, $\alpha 1$ and $\alpha 6$, both of which make heterodimers with the $\beta 1$ integrin subunit. Furthermore, we also investigated the expression of two splicing variants of the cytoplasmic domain of $\alpha 6$ integrin, $\alpha 6 \mathrm{~A}$ and $\alpha 6 \mathrm{~B}$, and of the cytoplasmic domain of $\beta 1$ integrin, $\beta 1 \mathrm{~A}$ and $\beta 1 \mathrm{~B}$. These variants are expressed in a tissue specific and cell type specific manner, ${ }^{18} 192728$ accompany the changes in amino acid sequences of their cytoplasmic domains, and mediate different signals. ${ }^{29-31}$

We used RT-PCR to investigate the gene expression of these adhesion molecules because this method made it possible to detect the small amounts of mRNA obtained from the tiny tissue samples. For the semiquantitative assay of these mRNAs, it is necessary to show that the amount of RT-PCR product is dependent on both the amount of RNA and the number of PCR cycles. ${ }^{20}$ We showed that the amount of RT-PCR products detected by densitometry correlated with the amount of RNA present and with the number of PCR cycles.

Our data showed that the expression of LBP and $\beta 1$ integrin was increased in fibrotic liver disease compared with normal liver tissue, and that the expression of LBP, $\alpha 6$ integrin, and $\beta 1$ integrin was further increased in HCC compared with corresponding non-cancerous liver tissue. When we compared LBP and $\alpha 6$ integrin in $\mathrm{HCC}$, the increase in $\alpha 6$ integrin expression was more prominent than that of LBP. These data suggest that the expression of laminin receptors is closely associated with the development and progression of HCC, and that they are differentially upregulated. It has been reported that in several malignant tumours including HCC, the expression of laminin receptors, including LBP and $\alpha 6$ integrin, correlates with invasiveness and metastatic activity, ${ }^{24} 25{ }^{32-34}$ as well as with malignant transformation. ${ }^{35}$ Furthermore, our results on the expression of the isoforms of $\alpha 6$ integrin and $\beta 1$ integrin show that the alternative splicing of these two integrins is also differentially regulated in non-cancerous liver tissue and HCC. Therefore, the altered splicing pattern of these integrins may contribute to the altered expression pattern of $\alpha 6 \beta 1$ integrin, and to the altered response of HCC cells to laminin because of the changes in the amino acid sequences of the cytoplasmic domain which mediates cellular-extracellular signalling.

In conclusion, this differential expression among laminin receptors and their isoforms in HCC may correspond to their different roles in cell-ECM interactions including the processes of malignant transformation, invasion, and metastasis. As most of our cases of HCC were advanced stage and had a similar histological grade, we could not show a relation between the expression of laminin receptors and the grade of the malignancy or disease progression, 
although we were able to show a close relation between the differential upregulation of laminin receptors and the development of HCC. Another point to be studied is which types of cells in HCC are responsible for the differential expression of these integrin molecules. To investigate the localisation and type of cells producing these integrin isoforms, immunohistochemical staining with specific antibodies or in situ hybridisation with specific probes, which can be analysed quantitatively, should be useful. Therefore, the expression and function of laminin receptors and their isoforms during hepatocarcinogenesis and tumour progression requires further study.

1 Liotta LA, Rao CN, Wewer UM. Biochemical interactions of tumor cells with the basement membrane. Ann Rev Biochem 1986;55:1037-57.

2 Timpl R, Rhode H, Robey PG, et al. Laminin-a glycoprotein from basement membranes. F Biol Chem 1979;254: 9933-7.

3 Brugeson RE, Chiquet M, Deutzmann R, et al. A new nomenclature for laminins. Matrix Biol 1994;14:209-11.

4 Miner JH, Patton BL, Lentz SI, et al. The laminin $\alpha$ chains: expression, developmental transitions, and chromosomal locations of $\alpha 1-5$, identification of heterotrimeric laminins $8-11$, and cloning of a novel $\alpha 3$ isoforms. $\mathcal{F}$ Cell Biol 1997 ; 8-11, and clonin 137 :685-701.

5 Iwamoto Y, Robey FA, Graf J, et al. YIGSR, a synthetic laminin penta peptide, inhibits metastasis formation. Science 1987;238:1132-4.

6 Sakamoto N, Iwahana M, Tanaka NG, et al. Inhibition of angiogenesis and tumor growth by a synthetic laminin peptide, CDPGYIGSR-NH2. Cancer Res 1991;51:903-6.

7 Kanemoto T, Reich R, Royce L, et al. Identification of an amino acid sequence from the laminin A chain that stimulates metastasis and collagenase IV production. Proc Nat Acad Sci USA 1990;87:2279-83.

8 Okuda K. Early recognition of hepatocellular carcinoma. Hepatology 1986;6:729-38.

9 Mecham R. Receptors for laminin on mammalian cells. FASEB f 1991;4:2538-46.

10 Edmondson HA, Steiner PE. Primary carcinoma of the liver: a study of 100 cases among 48,900 necropsies. $C A$ liver: a study of 100 cases am

11 Hermanek P, Sobin LH, eds. TNM classification of malignant tumors. 4th edn. Berlin: Springer Verlag, 1987.

12 Chirgwin JJ, Przybyla AE, MacDonald RJ, et al. Isolation of biologically active ribonuclear acid from sources enriched in ribonuclease. Biochemistry 1979;18:5294-9.

13 Briesewitz R, Epstein MR, Marcantonio E. Expression of native and truncated forms of the human integrin $\alpha 1$ subunit. F Biol Chem 1993;268:2989-96.

14 Tamura RN, Rozzo C, Starr L, et al. Epithelial integrin $\alpha 6 \beta 4$ : complete primary structure of $\alpha 6$ and variant forms of $\beta 4$. F Cell Biol 1990;111:1593-604.

15 Argraves WS, Suzuki S, Arai H, et al. Amino acid sequence of the human fibronectin receptor. F Cell Biol 1987;105: $1183-90$

16 Wewer UM, Liotta LA, Jaye M, et al. Altered levels of laminin receptor mRNA in various human carcinoma cells that have different abilities to bind laminin. Proc Natl Acad Sci USA 1986;83:7137-41.
17 Nakajima-Iijima S, Hamada H, Reddy P, et al. Molecular structure of the human cytoplasmic $\beta$-actin gene: interspe-
cies homology of sequences in the introns. Proc Natl Acad cies homology of sequences
Sci USA 1985;82:6133-7.

18 Tamura RN, Cooper HM, Collo G, et al. Cell type-specific integrin variants with alternative $\alpha$ chain cytoplasmic domains. Proc Natl Acad Sci USA 1991;88:10183-7.

19 Altruda F, Cervella P, Tarone G, et al. A human integrin $\beta 1$ subunit with a unique cytoplasmic domain generated by alternative mRNA processing. Gene 1990;95:261-6.

20 El-Deiry WS, Nelkin BD, Celano P, et al. High expression of the DNA methyltransferase gene characterizes human neoplastic cells and progression stages of colon cancer. Proc Natl Acad Sci USA 1991;88:3470-4.

21 Volpes R, van den Oord JJ, Desmet VJ. Distribution of the VLA family of integrins in normal and pathological human liver tissue. Gastroenterology 1991;101:200-6.

22 Couvelard A, Scoazec J-Y, Feldmann G. Expression of cellcell and cell-matrix adhesion proteins by sinusoidal endothelial cells in the normal and cirrhotic human liver. Am f Pathol 1993;143:738-52.

23 Grigioni WF, D'Errico A, Mancini AM, et al. Hepatocellular carcinoma: expression of basement membrane glycoproteins. An immunohistochemical approach. 7 Pathol proteins. An imm

24 Grigioni WF, Garbisa S, D'Errico A, et al. Evaluation of hepatocellular carcinoma aggressiveness by a panel of extracellular matrix antigens. Am f Pathol 1991;138:64754.

25 Volpes R, van den Oord JJ, Desmet VJ. Integrins as differential cell lineage markers of primary liver tumors. $A m \mathcal{F}$ Pathol 1993;142:1483-92.

26 Begum NA, Mori M, Matsumata T, et al. Differential display and integrin alpha6 messenger RNA overexpression in hepatocellular carcinoma. Hepatology 1995;22: $1447-55$

27 Hogervorst F, Admiraal LG, Niessen C, et al. Biochemical characterization and tissue distribution of the $\mathrm{A}$ and $\mathrm{B}$ variants of the integrin $\alpha 6$ subunit. 7 Cell Biol 1993;121:17991 .

28 Balzac F, Belkin AM, Koteliansky VE, et al. Expression and functional analysis of a cytoplasmic domain variant of the $\beta 1$ integrin subunit. 7 Cell Biol 1993;121:171-8.

29 Balzac F, Retta SF, Albini A, et al. Expression of $\beta 1 \mathrm{~B}$ integrin isoform in $\mathrm{CHO}$ cells results in a dominant negative effect on cell adhesion and motility. 7 Cell Biol 1994:127:557-65.

30 Shaw LM, Mercurio AM. Regulation of cellular interactions with laminin by integrin cytoplasmic domains: the A and B structural variants of $\alpha 6 \beta 1$ integrin differentially modulate the adhesive strength, morphology, and migration of macrophages. Mol Biol Cell 1994;5:679-90.

31 Shaw LM, Turner CE, Mercurio AM. The $\alpha 6 \beta 1$ and $\alpha 6 \beta 1$ integrin variants signal differences in the tyrosine phosphorylation of paxillin and other proteins. F Biol Chem 1995;270:23648-52.

32 Mafune K, Ravikumar TS, Wong JM, et al. Expression of an $\mathrm{Mr}$ 32,000 laminin-binding protein messenger RNA in human colon carcinoma correlates with disease progression. Cancer Res 1990;50:3888-92.

33 Ramos DM, Chen YF, Kramer R. Role of laminin-binding integrin in the invasion of basement membrane matrices by fibrosarcoma cells. Invasion Metastasis 1991;11:125-38.

34 Friedrichs K, Ruiz P, Franke F, et al. High expression level of $\alpha 6$ integrin in human breast carcinoma is correlated with reduced survival. Cancer Res 1995;55:901-6.

35 Lin CS, Zhang K, Kramer R. a6-integrin is up-regulated in step increments accompanying neoplastic transformation and tumorigenic conversion of human fibroblasts. Cancer Res 1993;53:2950-3. 